\title{
Energy Conservation in China's Road Transport: Policy Analysis
}

\author{
Xiaoyi He ${ }^{1}$, Xunmin $\mathrm{Ou}^{1,2^{*}}$, Xiliang Zhang ${ }^{1,2}$, Xu Zhang ${ }^{1,2}$, Qian Zhang ${ }^{1,2}$ \\ ${ }^{1}$ Institute of Energy, Environment and Economy, Tsinghua University, Beijing, China \\ ${ }^{2}$ China Automotive Energy Research Center, Tsinghua University, Beijing, China \\ Email: *ouxm@tsinghua.edu.cn
}

Received May 31, 2013; revised July 1, 2013; accepted July 28, 2013

Copyright (C) 2013 Xiaoyi He et al. This is an open access article distributed under the Creative Commons Attribution License, which permits unrestricted use, distribution, and reproduction in any medium, provided the original work is properly cited.

\begin{abstract}
Energy consumption for transport purposes has increased rapidly in China over the past decade. China's transport industry has undergone remarkable developments in energy conservation through structural, technological and managerial measures. The paper analyzes energy-conservation policies and measures related to road transport in China. The paper also identifies constraints for these policies and measures. The transport management authorities face a series of difficulties associated with methods, costs, public awareness, and management systems. Suggestions for improvement are also offered, including promotion of energy-efficient private vehicles, advances in business vehicle energy conservation, exploiting the energy potential of urban traffic and infrastructure development for energy-efficient clean vehicles.
\end{abstract}

Keywords: Energy Conservation; Road Transport; Policy Analysis; China

\section{Introduction}

Over the past decade, energy consumption for transport purposes has increased rapidly in China. This escalation is primarily accounted for by growing consumption of gasoline and diesel [1,2]. The freight transport sector has steadily improved its energy efficiency and reduced its energy intensity. The passenger transport sector, however, is likely to see a moderate increase in energy intensity in the near future because of a growing demand in service quality (i.e., speed, convenience, comfort) [3]. With the country's continuing industrialization and urbanization, energy consumption for transport purposes will continue to increase in the foreseeable future, and transport will gradually become a major energy user in the Chinese economy [4].

In recent years, China's transport industry has undergone remarkable developments in energy conservation through structural, technological and managerial measures. Nevertheless, a number of major problems remain to be solved. Through various policies, the local or national governments have actively encouraged public transport, inter-city rail transit construction, green travel, and energy conservation by means of structural and technological optimization. Despite positive initial results, the industry still faces enormous challenges, such as structural defects in the transport sector, inadequate public transport capability, and ineffec-

"Corresponding author. tive energy-management mechanisms and policies [5].

\section{Main Measures}

Energy conservation can be achieved primarily through two strategies (Figure 1): structural adjustment and technological advances. In practice, these strategies are refined into schemes (at a relatively macro-level) and measures (at a relatively micro-level). For these schemes and measures to take effect, governmental policies are required. With the continuing marketization of energyrelated sectors, the government regulates the operation of such sectors primarily by three groups of measures: price policies, fiscal and taxation policies, and other managerial policies [6,7].

Government policies take the form of laws and bylaws, governmental plans, and guideline documents. For a new policy to be effectively enforced in China, the government has to consider carefully multiple aspects of the issues at hand. In particular, the following elements need to be clearly defined: 1) the objectives of the policy; 2) the target objects of the policy; 3) the governmental departments responsible for policy enforcement; 4) procedures required to enforce the policy; 5) mechanisms for monitoring policy enforcement; and 6) the relationship between the present policy and preceding and subsequent ones.

Energy conservation in road transport is the key task in 


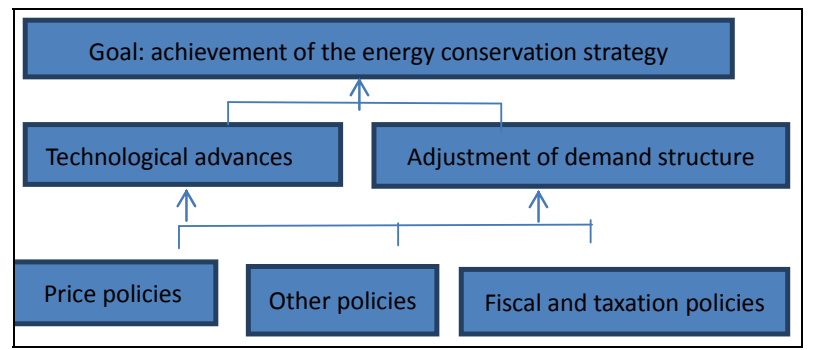

Figure 1. Relationship of the goal, strategies, and schemes (measures) in energy conservation.

transport energy conservation, and numerous policies, schemes, and measures are related to this task. The major ones are listed in Table 1.

\section{Restraints Analysis}

With respect to energy conservation, transport management authorities face a series of difficulties associated with methods, costs, public awareness, and management systems. They can be summarized as follows [8]: Finally, complete content and organizational editing before formatting. Please take note of the following items when proofreading spelling and grammar:

- Technological conditions. Some energy-conservation techniques are under development or at the demonstration stage and require funding support.

- Cost issues. The implementation of energy-conservation schemes involves increased costs and thus requires financial assistance.

- Limited public awareness. The importance of energy conservation and efficiency has not been widely recognized by corporate managers, appliances operators, and the general public.

- Weak management. Current systems for rating energy efficiency, energy conservation, and environmental protection are inadequate. Data are lacking. There are delays in the dissemination of energy conservationrelated information. Management measures do not function well.

Table 2 lists the constraints faced by transport management authorities in enforcing energy-conservation policies.

In particular, the impact of these energy policies on non-business (i.e., private-use) vehicles has been unsatisfactory. Achieving further improvement in the outcomes of these policies would appear to be an enormous challenge. The main factors that confine the outcomes of these policies are as follows. First, the ownership of private vehicles has increased rapidly. Correspondingly, the energy consumption by private vehicles has accelerated. Because of changing consumer habits, small vehicles are unlikely to become the first choice of vehicle for most people in the near future. Second, consumers are relatively insensitive to gasoline prices, which impede the transition to choosing more energy-efficient vehicles.

\section{Policy Recommendations}

\subsection{Consistent Promotion of Energy-Efficient Private Vehicles}

Motorized vehicles are the leading factor in rising fuel consumption. Experience in developed countries (Europe, Japan, United States) indicates that the most effective economic measures for improving the energy efficiency of vehicles are as follows: 1) issuing energy-efficiency standards and introducing fuel taxes; 2) requiring manufacturers to upgrade production techniques; and 3) encouraging consumers to purchase fuel-efficient vehicles. China should introduce energy-efficiency standards and promote the adoption of energy-conservation behavior and technologies as well as alternative-fuel vehicles.

\subsection{Comprehensive Advances in Business Vehicle Energy Conservation}

Energy conservation for business vehicles should proceed in terms of three aspects: vehicles, roads, and transport organization. First, it is necessary to reduce the energy consumption of vehicles. This can be achieved in two ways: energy-conservation techniques for new vehicles and the maintenance of existing vehicles. The former approach requires the regulation of manufacturers through relevant standards and policies. The latter approach is within the scope of transport management authorities and can be achieved in several ways: forced retirement of old energy-intensive vehicles; encouraging structural improvement for vehicles by means of economic incentives; rigorous monitoring of vehicle maintenance; and appropriate driver training.

Second, energy consumption can be attained by improving the road network structure and road conditions. It can also be achieved by optimizing transport organization and increasing transportation efficiency by improving the load efficiency.

Moreover, to ensure the long-term success of energy conservation in road transport, it is necessary to promote the inherent energy-conservation capacity in the transport sector and make energy conservation a customary procedure in this industry.

\subsection{Exploiting the Energy Potential of Urban Traffic}

Urban traffic involves many complex factors, such as management, policies and laws, planning, technology, operation management, and finance. Improvement in one or more of these factors can lead to advances in the traffic environment and efficiency, thereby contributing directly or indirectly to energy conservation. Thus, there is 
Table 1. Measures relevant to energy conservation in road transport.

\begin{tabular}{|c|c|c|}
\hline No & Energy conservation policies/measures & Objectives \\
\hline 1 & Recommend vehicle types for freight transport & \multirow{3}{*}{ Promote the use of energy-efficient vehicles } \\
\hline 2 & Encourage the use of heavy-load vehicles and van-type vehicles. & \\
\hline 3 & Promote diesel-fueled vehicles & \\
\hline 4 & Eliminate old vehicles & Eliminate energy-intensive vehicles from the transport market \\
\hline 5 & Upgrade vehicle maintenance and tests & \multirow{2}{*}{ Improve the energy efficiency of vehicles in operation } \\
\hline 6 & Recommend energy-efficient products & \\
\hline 7 & Encourage corporatization of passenger transport organizations & \multirow[b]{2}{*}{ Increase the transport efficiency } \\
\hline 8 & $\begin{array}{l}\text { Promote the use of information technology in freight and } \\
\text { passenger transport }\end{array}$ & \\
\hline 9 & Quota management of energy use and reward/punishment & \multirow{2}{*}{$\begin{array}{l}\text { Increase the awareness of energy conservation in staff working in } \\
\text { the transport sector }\end{array}$} \\
\hline 10 & Driver training & \\
\hline 11 & Construct national expressway networks & \multirow{4}{*}{$\begin{array}{l}\text { Improve the road network structure, road conditions, and its traffic } \\
\text { capacity }\end{array}$} \\
\hline 12 & Construct high-grade roads & \\
\hline 13 & Improve the pavement of roads & \\
\hline 14 & Control overweight and oversize in road transport & \\
\hline 15 & Offer toll discounts for heavy-load vehicles & Encourage the use of energy efficient vehicles \\
\hline
\end{tabular}

Table 2. Energy-conservation measures and constraints for enforcement in transportation sector.

\begin{tabular}{|c|c|c|c|}
\hline Scheme & Policy & Actual constraint & Type \\
\hline \multirow{5}{*}{$\begin{array}{l}\text { Adjustment of transport } \\
\text { structure }\end{array}$} & $\begin{array}{l}\text { Ensure the proportion of non-motorized } \\
\text { vehicles in traffic }\end{array}$ & $\begin{array}{l}\text { Local bylaws discouraging electric bikes; } \\
\text { inconvenience of traditional bikes }\end{array}$ & Public awareness \\
\hline & $\begin{array}{l}\text { Increase the proportion of train and water } \\
\text { transport in total transport load }\end{array}$ & $\begin{array}{l}\text { Unavailability of train passes; } \\
\text { low speed of water transport }\end{array}$ & Cost \\
\hline & $\begin{array}{l}\text { Increase the adoption of public transit in } \\
\text { traffic }\end{array}$ & $\begin{array}{l}\text { Crowdedness and lack of comfort in } \\
\text { buses; road congestion }\end{array}$ & Public awareness \\
\hline & $\begin{array}{l}\text { Increase the ratio of energy efficient } \\
\text { vehicles in passenger vehicles }\end{array}$ & $\begin{array}{l}\text { Energy benefit of small vehicles not necessarily } \\
\text { predominant relative to their advantages } \\
\text { (e.g., lack of impressive appearances) }\end{array}$ & Public awareness \\
\hline & $\begin{array}{l}\text { Increase the ratio of energy efficient } \\
\text { vehicles in business vehicles }\end{array}$ & $\begin{array}{l}\text { Energy benefit of large vehicles not necessarily } \\
\text { predominant relative to their advantages (high costs) }\end{array}$ & Cost \\
\hline \multirow{4}{*}{$\begin{array}{l}\text { Improvement of fuel } \\
\text { economics of vehicles }\end{array}$} & $\begin{array}{l}\text { Improve the energy standard of new } \\
\text { vehicles }\end{array}$ & $\begin{array}{l}\text { Differences in technological statuses of } \\
\text { vehicle manufacturers }\end{array}$ & $\begin{array}{l}\text { Technological } \\
\text { factors }\end{array}$ \\
\hline & $\begin{array}{l}\text { Eliminate energy intensive in-use } \\
\text { vehicles from the market }\end{array}$ & Vehicle owners unwilling to abandon existing vehicles & Cost \\
\hline & $\begin{array}{l}\text { Increase the proportion of } \\
\text { diesel-fueled vehicles }\end{array}$ & $\begin{array}{l}\text { Limited diesel availability; emission of black } \\
\text { smoke and exhaust from diesel-fueled vehicles }\end{array}$ & Cost \\
\hline & $\begin{array}{l}\text { Increase the proportion of hybrid } \\
\text { electric vehicles (HEVs) }\end{array}$ & High costs of HEVs & Cost \\
\hline $\begin{array}{l}\text { Promotion of alternative } \\
\text { fuels }\end{array}$ & $\begin{array}{l}\text { Increase the proportion of alternative-fuel } \\
\text { vehicles such as electric vehicles (EVs) }\end{array}$ & $\begin{array}{l}\text { Technological defects of alternative-fuel } \\
\text { vehicles; inconvenience in recharging }\end{array}$ & Cost \\
\hline \multirow{3}{*}{$\begin{array}{l}\text { Improvement of road } \\
\text { networks }\end{array}$} & Improve the road network structure & Road congestion & Weak management \\
\hline & Improve the road conditions & Road surface damage & Weak management \\
\hline & Improve the traffic capability & Too many tolling points & Weak management \\
\hline \multirow{5}{*}{$\begin{array}{l}\text { Other managerial } \\
\text { measures }\end{array}$} & Control energy use in subsectors & Lack of clear goals & Weak management \\
\hline & $\begin{array}{l}\text { Upgrade energy conservation-related } \\
\text { monitoring and examination }\end{array}$ & Lack of a clear system & Weak management \\
\hline & $\begin{array}{l}\text { Encourage the use of energy } \\
\text { conserving products and techniques }\end{array}$ & Lack of motivation & Cost \\
\hline & $\begin{array}{l}\text { Perform comprehensive management of } \\
\text { energy policies }\end{array}$ & Current laws need revisions & Weak management \\
\hline & \multicolumn{2}{|c|}{ Improve the public concept of vehicle use Lack of leaders } & Public awareness \\
\hline
\end{tabular}


enormous potential for energy conservation in urban traffic.

Fuel use by urban vehicles accounts for over half of total vehicular energy consumption. Additionally, urban vehicles feature high spatial density, and there is a large proportion of small urban vehicles. As a result, urban vehicles represent a vast market potential for the application of alternative fuels.

Global experience has shown that the operation efficiency of urban traffic can be improved by such approaches as managing transport demand and improving the traffic supply. More specifically, improvements can be achieved by the following practices: limiting the use of private vehicles; introducing (or increasing) the fuel tax, exhaust emission tax, parking fees, and extra fees for traffic during peak hours and in those regions congested usually; creating bus-only lanes; using automatic traffic control systems; and developing rail transit networks. All these practices can contribute to improved energy efficiency.

\subsection{Infrastructure Development for Energy-Efficient Clean Vehicles}

The government needs to expedite the infrastructure development for clean vehicles. The infrastructure provides the essential conditions and support for growth of the alternative-fuel vehicle industry. Cleaner vehicles can reduce the emission of greenhouse gases and pollutants. Charging stations (or posts) and natural-gas fueling stations can be constructed in cities selected for the promotion of alternative-fuel vehicles, such as hybrid electric vehicles, electric vehicles, and vehicles fueled by compressed or liquefied natural gas. Moreover, intensive research should focus on the development of high-performance batteries and energy-storage devices. Efforts need to be made to develop technical capabilities and standard systems for the manufacture, licensing, and quality control of energy-supplying equipment.

\section{Acknowledgements}

The project is co-supported by the China National Natural Science Foundation (Grant No.71103109, and 71073095) and the CAERC program (Tsinghua/ GM/SAIC-China).

\section{REFERENCES}

[1] Energy Research Institute of China (ERI), “China Energy Outlook," China Economic Publishing House, Beijing, 2012.

[2] China Automotive Energy Research Center, Tsinghua University (CAERC), "China Automotive Energy Outlook 2012,” Scientific Press, Beijing, 2012.

[3] Ministry of Transportation of China (MOT), “2011 China Transportation Energy Saving, Emission Reduction and Low Carbon Development Annual Report,” China Communications Press, Beijing, 2012.

[4] X.M. Ou, X.L. Zhang and S.Y. Chang, "Scenario Analysis on Alternative Fuel/Vehicle for China's Future Road Transport: Life-Cycle Energy Demand and GHG Emissions,” Energy Policy, Vol. 38, No. 8, 2010, pp. 39433956. doi:10.1016/j.enpol.2010.03.018

[5] China Energy Research Association (CERS), "China Energy Development Report 2012,” China Electric Power Press, Beijing, 2012.

[6] X. Y. Yan and R. J. Crookes, "Reduction Potentials of Energy Demand and GHG Emissions in China's Road Transport Sector,” Energy Policy, Vol. 37, No. 2, 2009, pp. 658-668. doi:10.1016/j.enpol.2008.10.008

[7] Y. D. Dai and Q. Bai, “Overview of China’s Energy Conservation Progress (2006-2010)," China Economic Publishing House, Beijing, 2012.

[8] International Energy Agency (IEA), “Energy Technology Perspective,” IEA, Paris, 2008. 